\title{
CONFERENCE REPORT: 3RD INTERNATIONAL WORKSHOP ON LAW AND IDEOLOGY ON THE "RULE OF LAW AND THE POLITICS OF CONFLICT", JAVAKHISHVILI TBILISI STATE UNIVERSITY, TBILISI, GEORGIA, 23-24 MAY 2016
}

\author{
RAFAL MAŃKO*
}

On 23-24 May 2017 the Tsereteli Institute of State and Law at the Javakhishvili Tbilisi State University in Tbilisi, Georgia, hosted the 3rd International Workshop on Law and Ideology devoted to the "Rule of Law and the Politics of Conflict". The conference was co-organised by the Javakhishvili Tbilisi State University jointly with the Centre for Legal Education and Social Theory at the University of Wroclaw, under the auspices of the Central and Eastern European Network of Legal Scholars (CEENELS). ${ }^{1}$ The Organisational Committee of the Workshop was composed of Dr. Lasha Brekvadze (Javakhishvili Tbilisi State University), Dr. Rafał Mańko (University of Amsterdam, CEENELS) and Adv. Michał Stambulski (Wroclaw Bar Association, CLEST). The International Workshops on Law and Ideology $y^{2}$ have been organised since 2014 with aim of providing a forum for young scholars from Central and Eastern Europe interested in exploring critical legal theory. The 1st Workshop was held at the University of Wroclaw and was focused on exploring the interplay between the concepts of law and ideology, especially from the perspective of Marx, Lacan and Žižek, as well as on alternative critical narratives, especially the

DOI: $10.1515 /$ wrlae-2018-0012

* PhD in Law (University of Amsterdam). External Fellow, Centre for the Study of European Contract Law, University of Amsterdam. Email: $\underline{\text { r.t.manko@uva.nl. }}$

${ }^{1}$ The Central and Eastern European Network of Legal Scholars was created in April 2015 in Brno. For more details see W Zomerski, 'Conference Report: $1^{\text {st }}$ International Conference of the Central and Eastern European Network of Legal Scholars (CEENELS) on "25 Years After the Transformation: Law and Legal Culture in Central and Eastern Europe Between Continuity and Discontinuity", Masaryk University, Brno, 16-17 April 2015' (2014) 4.2 Wroclaw Review of Law, Administration and Economics. See also the official CEENELS website: http://www.ceenels.org [11/6/2017].

${ }^{2}$ For a general presentation of the idea of the Workshops see R Mańko, M Stambulski, 'Law and Ideology: Critical Explorations' (2015) 5.1 Wroclaw Review of Law, Administration and Economics. 
concepts of episteme (Foucault) and doxa (Bourdieu). ${ }^{3}$ Following the success of the first workshop, the second was held at the University of Sarajevo (organisers: Samir Forić, Rafał Mańko, Michał Stambulski) and the topic was concerned with Memories of Struggles, Struggles of Memory. ${ }^{4}$ Selected papers from the 1st and 2nd Workshops were published in a special issue of the Wroclaw Review of Law, Administration and Economics. ${ }^{5}$

The 3rd Workshop on Law and Ideology was spread over two days. The conference was opened by Dr. Lasha Brekvadze and Dr. Rafał Mańko, who welcomed the participants on behalf of the Organising Committee. Following that, a keynote lecture was delivered by Professor Adam Czarnota (Director of the Oñati International Institute for the Sociology of Law) who spoke about Transformation from Communism and the Rule of Law.

The further conference proceedings were divided into consecutive panels of two to three papers. Panel I, devoted to Rule of Law and the Political comprised two papers.

Ursus Eijkelenberg (Master's Student, International Institute for the Sociology of Law, Oñati) spoke about Disclosing the democratic façade. Approaching the subsequent step of democratic evolution, and Adv. Michał Stambulski (Executive Director, Centre for Legal Education and Social Theory, University of Wroclaw) delivered a paper entitled The Law vs the People. On two approaches to the public sphere and constitutionalism. Panel II was devoted to The Ontology of the Rule of Law. Dr. Rafał Mańko (University of Amsterdam): Rule of Law Between Form and Substance: The Ideological Implications of Legal Argumentation and Dr. Antonios Platsas (Higher School of Economics - National Research University, Moscow) delivered a paper entitled At the Crossroads of Law and Ideology: Ideology of Law as Reflection of Social Ontology? Following the first two theoretical panels, the following one, Panel III, took a more practical approach, being devoted to The Polish Constitutional Crisis in Perspective. Dr. Paulina Święcicka (Roman Law Departmetnt, Jagiellonian University, Krakow) and Dr. Marek Stus (Legal History Department, Jagiellonian University) jointly delivered a paper entitled Dilemmas of Polish Democracy: Strong State, Strong Political Power and the Force of Law in the Light of Legislative Changes of 2015/2016. The second paper was delivered by Mgr. Łukasz Necio (PhD Candidate, Jagiellonian University, Poland) and was entitled Agonistic Liberalism in Central Europe? The Polish Constitutional Crisis as a Reason for Beginning a Discourse in New Categories.

The second day of the conference comprised three subsequent panels. Panel IV, entitled Law and Politics in Central and Eastern Europe was composed of three papers. Dr. Michał Paździora (Director, Centre for Legal

\footnotetext{
${ }^{3}$ For a report from the Workshop see R Mańko, W Kauczor and W Zomerski, 'Conference Report: $1^{\text {st }}$ International Workshop on Law and Ideology (Wrocław, 29-30 May 2014)' (2013) 3.2 Wroclaw Review of Law, Administration and Economics.

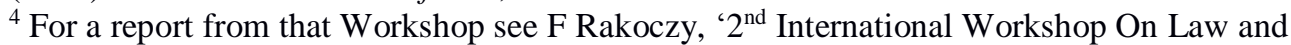
Ideology "Memories of Struggles, Struggles of Memories", Sarajevo, 28-29 May 2015' (2015) 11 Archiwum Filozofii Prawa i Filozofii Społecznej 157-160.

${ }^{5}$ See: (2015) 5.1 Wroclaw Review of Law, Administration and Economics.
} 
Education and Social Theory, University of Wroclaw), delivered a paper entitled Beyond Harmony and Disagreement: A History of Precedents Which Have Never Been; Dr. Lucian Bojin (Assistant Professor, West University, Timişoara, Romania) presented a paper entitled Romanian Politics and the Voice of the "Street": 2012-2105 and Mgr. Filip Cyuńczyk (PhD Candidate, University of Bialystok): Memory - an Area of Struggle and Its Institutionalisation in Post-Communist Central and Eastern Europe.

Panel V was devoted to Rule of Law and Conflict Resolution and was composed of two papers. Mgr. Piotr Eckhardt (PhD Candidate, Jagiellonian University) spoke about the Crisis of the European Union as a Crisis of the Rule of Law in Conflict Resolution on Supranational Level and Dr. Lasha Bregvadze (Javakhishvili Tbilisi State University) delivered a paper on the Rule of Law vs. Rule of Functional Differentiation: Systems Theory and Law Reform.

Panel VI was the last one and was devoted to Antagonism in the Public Sphere. Papers were delivered by Mgr. Marcin Wróbel (PhD candidate in law, Jagiellonian University) on Pushing Conflicts out of the Public Sphere: Alternative Dispute Resolution as the Privatization of Law and Mgr. Jolanta Sawicka (PhD Candidate, Instute of Political Philosophy, Univeristy of Warsaw) whose paper was entitled An Emancipatory Meaning of Divisions and Political Antagonisms. The Theory of Claude Lefort.

Following the panels, the participants discussed the future of the International Workshops on Law and Ideology and accepted the offer of Dr. Lucian Bojin to organise the next one at the West University in Timişoara, Romania. 